\title{
Protective effect of silk protein hydrolysates against tert-BHP induced liver damage
}

\author{
Joo Hyoun Kim ${ }^{1}$, Hyung Joo $\mathrm{Suh}^{2}$, Hyeon-Son Choi ${ }^{1 *}$ \\ ${ }^{1}$ Department of Food Science and Technology, Seoul Women's University, Seoul 01797, Korea \\ ${ }^{2}$ Department of Food and Nutrition, Korea University, Seoul 02841, Korea \\ 실크 단백질 가수분해물의 간 손상에 대한 보호효과 \\ 김주현 ${ }^{1} \cdot$ 서형주 $^{2} \cdot$ 최현선 $^{1 *}$ \\ ${ }^{1}$ 서울여자대학교 자연과학대학 식품공학과, ${ }^{2}$ 고려대학교 보건과학대학 식품영양학과
}

\begin{abstract}
The aim of this study was to investigate the hepatoprotecive effect of silk protein hydrolysates (SDH), which was prepared by acid hydrolysis, in rats. SDH itself did not exhibit any cytotoxic effect on hepatic tissues. SDH showed a protective effect on tert-butyl hydroperoxide ( $t$-BHP)-induced hepatotoxicity and liver damage. SDH effectively reduced AST (aspartate aminotransferase) and ALT (alanine aminotransferase), which are biomarkers for liver damage, in a dose-dependent manner. Malondialdehyde (MDA), a lipid peroxidation product, was significantly reduced by SDH. A high dose of SDH $(2 \mathrm{~g} / \mathrm{kg})$ reduced $t$-BHP-induced MDA production by $40 \%$. Glutathione (GSH), which is an endogenous antioxidant molecule, was effectively increased by SDH treatment. GSH content was enhanced by around 2.5 -fold, compared with $t$-BHP control, upon SDH $(2 \mathrm{~g} / \mathrm{kg})$ treatment. Lactate dehydrogenase (LDH), which is an enzyme released by cell cytotoxicity, was greatly increased by $t$-BHP, but significantly decreased by SDH treatment. Furthermore, hematoxylin and eosin (H\&E) staining showed that SDH suppressed $t$-BHP-induced lesions in liver tissue. Taken together, SDH might be used as a protective agent against liver damage.
\end{abstract}

Key words : silk proteins, hepatoprotective effect, liver damage, tert-butyl hydroperoxide

\section{서 론}

간은 체중의 $3 \%$ 를 차지하는 장기로서 인체에서 물질의 대사, 합성, 저장 및 생체 내 전환 등에 중요한 역할을 한다. 특히, 탄수화물, 단백질, 지방, 핵산 및 비타민류 등의 생합 성 및 분해에 중추적인 역할을 하며 담즙을 생성하여 지방 성분의 소화와 흡수를 도울 뿐 아니라 체내 독성물질들에 대한 포합작용을 통해 신장이나 담즙으로 배설되기 쉬운 형태로 전환시킨다. 또한 에너지원으로 사용되고 남은 당 을 글리코겐형태로 저장하여 당 대사에도 중요한 역할을

*Corresponding author. E-mail : hschoi@swu.ac.kr Phone : 82-2-970-5683, Fax : 82-2-970-5977

Received 6 December 2016; Revised 1 January 2017; Accepted 1 January 2017.

Copyright (c) The Korean Society of Food Preservation. All rights reserved.
하는 등 매우 다양한 기능을 수행한다(1).

간 손상의 원인으로는 알코올, 흡연 외에도 바이러스에 의한 감염, 독물 또는 약제에 의한 중독, 영양장해 및 순환장 해 같은 신변의 원인 등이 있으며 최근 생활수준 향상에 따른 식생활의 변화와 현대 생활의 복잡성에서 오는 많은 스트레스도 발병인자로 볼 수 있다(2). 특히, 산화적 스트레 스에 의한 반응성 유해 산소종(reactive oxygen species; $\mathrm{ROS}$ )의 생성은 자유 라디칼(free radical) 로서 생체 내 다른 분자들과 무작위적인 반응을 통해 노화, 염증, 발암, 동맥경 화뿐 아니라 간섬유화, 신장염, 피부질환, 당뇨병 등의 여러 가지 질환의 원인이 되는 것으로 알려져 있다 $(3,4)$. 불포화 지방산이 풍부한 세포막은 생성된 자유 라디칼에 의해서 지질과산화의 표적이 되어 과도한 과산물의 생성을 통해 세포 소기관들이 정상적인 구조 및 기능을 잃게 되고, 세포 손상을 초래하게 된다(5).

바쁜 현대인들의 생활에서 간 손상 및 간 기능 저하에서 
비롯된 피로와 노동력의 감소는 웰빙 문화를 지향하는 현대 에서 극복해야 할 건강적인 이슈임에 틀림없다. 간기능 장 애와 손상에 따른 간장 질환의 비율이 날로 증가함에 따라 개인, 가정, 사회에 부정적인 영향을 미침으로써 국가적으 로도 막대한 경제-사회적 손실을 초래하고 있다. 따라서 간 기능 소재를 개발하여 응용하는 것은 간질환 치료와 예방 차원뿐만 아니라 개인, 사회, 국가적으로 필요한 것이 라 하겠다. 특히, 임상적 효과나 적은 부작용면에서 천연물 유래 간질환 개선제의 개발은 현재 꾸준히 진행되고 있음에 도 여전히 충분하게 이루어지지 않고 있다. 특히 그의 활성 성분과 효능에 대한 상관연구는 더욱 미진한 실정이다.

실크 펩타이드는 실크의 원료인 명주실이 저분자인 아미 노산끼리의 결합상태로 분해, 생성된 물질이며, 신체의 세 포와 조직을 활성화하고 세포의 정상적인 성장과 분열에 필요한 18종의 아미노산을 많이 함유하고 있다(6). 실크 펩타이드의 주 원료가 되는 누에고치는 2 종류의 단백질인 피브로인과 세리신이 $3: 1$ 의 비율로 구성되어 있다. 보통 실크는 견사의 바깥부분에서 세리신을 제거한 후 남은 단백 질인 피브로인을 말하며 한 가닥의 실크에서의 피브로인은 약 4,000 개 이상의 아미노산으로 구성되어 있다(6,7). 피브 로인은 우유나 달걀 등의 다른 식품소재의 아미노산과 비교 해 글리신과 알라닌의 함량이 특히 높은 것으로 알려져 있으며 필수아미노산은 약 $6 \%$ 정도 포함되어 있다. 실크 단백질은 소화 흡수력 면에서 다른 육류소재의 단백질에 비하여 탁월하며, 흡수될 때 칼슘, 철분과 같은 다른 영양소 도 같이 흡수되는 것으로 알려져 있다(6,7). 실크 펩타이드 의 기능성에 대한 연구는 다양하게 이뤄져 왔으며 산화스트 레스 억제, 콜레스테롤 저하, 헐당강하, 항종양 효과와 같은 생리활성들(8-11)이 알려져 있다. 하지만 아직까지 실크 펩 타이드의 간 보호효과에 대한 연구는 체계적으로 이루어지 지 않았다. 본 연구에서는 동물모델에서 실크단백질 산 가 수분해물의 항산화 활성 및 간 손상에 대한 보호효과를 조사하고 천연물 유래 간 질환 개선제에 대한 기초자료를 제공하고자 한다.

\section{재료 및 방법}

\section{시 료}

누에의 고치부분 $100 \mathrm{~g}$ 을 적당한 크기 $(3-4 \mathrm{~cm})$ 로 절단한 후 $\mathrm{Na}_{2} \mathrm{CO}_{3}(0.5 \%)$ 용액에서 30 분간 끓여 고치부분의 불순물 을 제거하였다. 불순물이 제거된 누에고치는 Hwang 등(8) 의 방법에 따라 산 가수분해를 실시하였다. 누에고치와 2 $\mathrm{N} \mathrm{HCl}$ 용액을 $1: 50$ 의 비율로 섞어서 48 시간동안 $100^{\circ} \mathrm{C}$ 에서 가수분해 한 후 $5 \% \mathrm{NaOH}$ 용액을 가하여 중화시켰다. 중화 시 생성된 염은 투석을 이용하여 제거하였고 동결 건조하여 시료로 사용하였다.

\section{동물실험}

연구 그룹은 무작위 추출법에 의해 군당 8 주령 $\mathrm{SD}$ rat 5 마리씩 6 개군으로 분류하였다. 실험대조군은 실험군과 동 일한 스트레스를 주기 위해 생리식염수를 경구 투여한 대조 군, 생리식염수 처리대신 시료(실크단백질 산 가수분해물 $2 \mathrm{~g} / \mathrm{kg}$ )만 처리한 군, 생리식염수 투여 후 $t$-BHP를 투여한 군, 시료를 $0.5 \mathrm{~g} / \mathrm{kg}$ 농도로 투여한 뒤 $t \mathrm{BHP}$ 를 투여한 군, 시료를 $1 \mathrm{~g} / \mathrm{kg}$ 농도로 투여한 뒤 $t \mathrm{BHP}$ 를 투여한 군, 시료를 $2 \mathrm{~g} / \mathrm{kg}$ 농도로 투여한 뒤 $t \mathrm{BHP}$ 를 투여한 군으로 분류하였다 (12). 시험 물질은 임상적용 경로를 따라 경구로 투여하였으 며, 투여기간은 1 일 1 회 7 일 동안 반복 투여하였다. 각 개체 가 해당하는 군의 평균 체중 기준으로 그 군에 해당하는 용량에 맞게 생리식염수에 시험물질을 용해시켜 마리당 $2 \mathrm{~mL} /$ day로 경구 투여하였다(12). 본 실험은 고려대학교 동물실험 윤리위원회의 심의를 받아 수행되었다 (KUIACUC-2010-141).

\section{혈 액생화학적 검사}

$t \mathrm{BHP}$ 를 처리한 군, 처리하지 않은 군 모두 $t \mathrm{BHP}$ 를 투여한 지 18 시간 뒤에 실험을 진행하였다. 실험 종료 시점에서 12시간 절식시킨 실험 동물을 ethyl ether로 마취시켜 희생 시킨 후 흥강을 열고 대동맥에서 혈액을 채취하여 일부를 시험관에 넣어 30 분 뒤 $4{ }^{\circ} \mathrm{C}, 3,000 \times g$ 에서 10 분간 원심분리 하고 상징액인 혈청을 분리하여 total protein(T. Protein), albumin, total bilirubin, Alkaline phosphatase(ALP), Aspartate Aminotransferase(AST), Alanine Aminotransferase(ALT), total cholesterol(T. Chol), glucose의 양을 표준시약 키트 (Roche Diagnostics GmbH, USA)와 Fuji Dri-Chem 3500(Fuji Photo Film Co., Osaka, Japan)을 이용하여 분석하였다.

\section{혈액학적 조직 병리학적 검사}

$t \mathrm{BHP}$ 를 처리한 군, 처리하지 않은 군 모두 $t \mathrm{BHP}$ 를 투여 한지 18 시간 뒤에 실험을 진행하였다. 실험 종료 시점에서 12시간 절식시킨 실험 동물을 ethyl ether로 마취시켜 희생 시킨 후 흥강을 열고 대동맥에서 혈액을 채취하여 일부를 EDTA가 처리된 채혈관에 넣어 잘 혼합하고 혈액응고를 방지한 뒤 녹십자 의료재단 임상연구팀에 백혈구수(WBC, white blood cell count), 적혈구수(RBC, red blood cell count), 혈색소량( $\mathrm{Hb}$, hemoglobin concentration), 헤마토크리트치 (HCt,hematocrit), 평균적혈구용적(MCV, mean corpuscular hemoglobin volume), 평균적혈구혈색소농도(MCHC, mean corpuscular hemoglobin concentration), 혈소판(PLT, platelet) 의 측정을 의뢰하였다. 조직 병리학적 검사를 위해 혈액채 취후 간, 신장 적출하여 무게를 측정하였다. 측정이 끝난 간과 신장은 포름 알데하이드 용액에 넣어 고정한 뒤 다음 날 새로운 포름 알데하이드로 교환하여 충분히 고정시킨 후 일반적인 조직처리 과정을 거쳐 파라핀 포매, 박절하였 
다. 간의 경우에는 hematoxylin \& eosin(H\&E) 염색을 하여 조직을 광학 현미경(Olympus BX51 microscope, Olympus America Inc., Center Valley, PA, USA) 으로 관찰하였으며 신장의 경우에는 periodic acid 염색(PAS)을 하여 현미경으 로 조직을 검사하였다. 장착된 MicroFire 2.2 digital camera(Optronics, Goleta, CA, USA)를 사용하여 해상도 $300 \mathrm{dpi}$ 이상에서 이미지를 얻고 비교하였다. 신장의 경우 에는 periodic acid 염색을 하여 조직을 검사하였다.

\section{$\mathrm{HPLC}$ 를 이용한 GSH 분석}

간조직 $1 \mathrm{~g}$ 당 $50 \mathrm{mM}$ Nethylmaleimide(NEM) 용액 $9 \mathrm{~mL}$ 가하여 빙냉하에서 마쇄한 균질액을 얻었고, $4^{\circ} \mathrm{C}, 600 \times g$ 에 서 10 분간 원심분리하여 핵 및 미마쇄 부분을 제거한 상층 액을 얻었다. NEM $1 \mathrm{~mL}$ 에 상층액 $100 \mu \mathrm{L}$ 를 넣어 섞고 $\mathrm{PCA}$ (perchloric acid) $60 \%$ 용액을 최종농도가 $5 \%$ 되도록 가 한 뒤 5 분간 얼음에 방치 후 $1,000 \times g$ 에서 1 분간 원심분리 하여 상층액 $1 \mathrm{~mL}$ 을 취하였다. 여기에 $50 \mathrm{mM}$ iodoacetate (IAA)용액 $100 \mu \mathrm{L}$ 를 가하여 잘 섞고 탄산수소 칼륨(1M potassium hydrogen carbonate)시약을 거품이 생기지 않을 때까지 가하여준 뒤 암소에서 20 분간 반응시켰다. 원심분 리하여 얻은 상층액에 동량의 3\% Fluoro-2,4-dinitrobenzene $(\mathrm{FDNB})$ 를 가하여 $4^{\circ} \mathrm{C}$ 의 암소에서 보관한 뒤 다음날 원심분 리 하여 상층액만 분석에 사용하였다(13). GSH와 GSSG의 표준물질로는 sigma사에서 구입한 시약을 사용하여 standard curve를 작성, 정량하였다. 두 물질을 동시에 분석하기 위한 분석조건은 다음과 같다; 메탄올과 물을 $4: 1(\mathrm{v}: \mathrm{v})$ 로 혼합한 용매 $\mathrm{A}$ 와 sodium acetate trihydrate $(272 \mathrm{~g})$ 와 $122 \mathrm{~mL}$ 의 증류수 그리고 $378 \mathrm{~mL}$ 의 glacial acetic acid가 혼합된 용액 $200 \mathrm{~mL}$ 에 용매 A $800 \mathrm{~mL}$ 을 혼합한 용매 B용액을 각각 $95 \%$ 에서 $70 \%, 5 \%$ 에서 $30 \%$ 로 농도기울기를 설정하여 60 분동안 진행하였다. 이때 컬럼은 OptimaPak $\mathrm{NH}_{2} 5 \mu$ $\mathrm{m}(4.6 \times 250 \mathrm{~mm})$ 를 사용하였으며 용매흐름 속도는 1 $\mathrm{mL} / \mathrm{min}, \mathrm{GSH}$ 의 검출파장은 $365 \mathrm{~nm}$, 주입량은 $100 \mu \mathrm{L}$ 이다.

\section{Malonaldehyde (MDA) 분석}

간 조직 $1 \mathrm{~g}$ 당 $1.15 \% \mathrm{KCl}$ 용액 $9 \mathrm{~mL}$ 를 가하여 빙냉하에서 마쇄한 균질 액을 얻었으며, $4^{\circ} \mathrm{C}, 600 \times \mathrm{g}$ 에서 10 분간 원심 분리하여 핵 및 미마쇄 부분을 제거한 상층액을 얻었다. 상층액 $0.1 \mathrm{~mL}$ 에 $8.1 \% \mathrm{SDS}$ 용액을 $0.2 \mathrm{~mL}$ 가하고 $20 \%$ acetic acid solution을 $1.5 \mathrm{~mL}$ 를 가하여 $0.8 \%$ thiobarbituric $\operatorname{acid}(\mathrm{TBA})$ 를 $1.5 \mathrm{~mL}$ 가한 후 총 $4 \mathrm{~mL}$ 이 되도록 맞춘 뒤 $95^{\circ} \mathrm{C}$ 에서 60 분간 반응시킨다. 반응이 끝난 후 냉각시키고 증류수를 $1 \mathrm{~mL}$ 가하고 $5 \mathrm{~mL}$ 의 butanol:pyridine=15:1의 용 액을 가하여 잘 섞어준 뒤 $2,000 \times g$ 에서 10 분간 원심 분리하 여 분리된 상층액을 Excitation $515 \mathrm{~nm} /$ Emission $552 \mathrm{~nm}$ 에 서 측정하였다(14).

\section{결과 및 고찰}

\section{혈 액 생화학적 검사}

실크 단백질 산 가수분해물만 처리한 군에서의 혈액 생 화학적 수치는 정상군과 비교해서 비슷한 결과를 나타내어 실크 단백질 산 가수분해물의 실험동물에 대한 독성을 비롯 한 부작용은 없는 것으로 판단 된다(Table 1). 그러나 간세포 및 간 기능의 손상과 연관 있는 여러 지표들에서 $t \mathrm{BHP}$ 를 처리한 군에서 유의적인 변화가 관찰되었다(Table 2). 본 실험에서 대조군으로 사용된 $t \mathrm{BHP}$ 는 여러 연구에서 세포 내 독성을 유발함으로써 세포 내 변화과정을 관찰할 때 사용되는 대표적인 화합물로 알려져 있다(15). AST와 ALT 는 간세포 누출효소로 간세포의 괴사와 간 조직의 파괴가 진행됨에 따라 효소가 혈중으로 유리되어 나타나므로 간 독성 연구에 활용되고 있다(16). $t \mathrm{BHP}$ 를 처리한 군에서는 간세포의 기능을 나타내는 지표들인 $\mathrm{AST}$ 가 정상군 $(146.4 \pm 6.63 \mathrm{U} / \mathrm{L})$ 에 비해 유의적으로 증가 $(196.2 \pm 16.99$ $\mathrm{U} / \mathrm{L}$ )하였고 ALT 역시 45.2 $\pm 1.71 \mathrm{U} / \mathrm{L}$ 에서 83.0 $\pm 3.91 \mathrm{U} / \mathrm{L}$ 로 증가하는 것이 관찰되었다. 이는 $t \mathrm{BHP}$ 가 실험동물의 간의 손상에 기여했음을 보여준다. $t \mathrm{BHP}$ 는 세포 내 대사 중 활성산소를 비롯한 여러 라디칼 들의 생성을 촉진함으로써 세포 내 산화 스트레스를 증가시켜 간 세포의 손상을 유발 시키는 것으로 사료된다(16). $t \mathrm{BHP}$ 에 의한 $\mathrm{AST} / \mathrm{ALT}$ 의 증 가가 시료인 실크 단백질 산 가수분해물에 의해 유의적으로 감소하였다(Table 2). 고농도의 처리시 $(2 \mathrm{~g} / \mathrm{kg})$ AST는 $26 \%$, $\mathrm{ALT}$ 는 $39 \%$ 감소하여 실크 단백질 산 가수분해물에 의한 간 기능 개선 효과가 확인되었다. 또한, 세포 독성을 나타내 는 또 다른 지표중의 하나인 $\mathrm{LDH}$ 의 수치도 정상군에 비해 $t \mathrm{BHP}$ 의 투여군에서 2 배 넘게 크게 증가했으며 실크 단백 질 산 가수분해물의 투여에 의해 $\mathrm{LDH}$ 의 수치가 유의적으 로 감소하였다. $\mathrm{LDH}$ 는 해당계 효소로서 체내의 각 조직에

Table 1. Blood biochemical test on administration of silk protein hydrolysates

\begin{tabular}{ccccc}
\hline \multirow{2}{*}{ Item } & \multicolumn{4}{c}{ Silk protein hydrolysates $(\mathrm{g} / \mathrm{kg})$} \\
\cline { 2 - 5 } & 0 & 0.5 & 1 & 2 \\
\hline T. Protein ${ }^{1)}(\mathrm{g} / \mathrm{dL})$ & $60 . \pm 0.11^{\text {ns })}$ & $6.1 \pm 0.10^{\text {ns }}$ & $6.1 \pm 0.04^{\text {ns }}$ & $6.0 \pm 0.06^{\text {ns }}$ \\
Albumin (g/dL) & $3.8 \pm 0.09^{\text {ns }}$ & $3.8 \pm 0.07^{\text {ns }}$ & $3.9 \pm 0.04^{\text {ns }}$ & $3.8 \pm 0.04^{\text {ns }}$ \\
ALP (U/L) & $272.8 \pm 34.10^{\text {ns }}$ & $278 \pm 15.99^{\text {ns }}$ & $297.5 \pm 37.78^{\text {ns }}$ & $270 \pm 41.85^{\text {ns }}$ \\
AST (U/L) & $146.4 \pm 10.63^{\text {ns }}$ & $158.0 \pm 9.47^{\text {ns }}$ & $160.0 \pm 18.38^{\text {ns }}$ & $171.8 \pm 16.34^{\text {ns }}$ \\
ALT (U/L) & $45.2 \pm 4.7^{\text {ns }}$ & $42.5 \pm 2.70^{\text {ns }}$ & $47.5 \pm 3.91^{\text {ns }}$ & $46.0 \pm 3.41^{\text {ns }}$ \\
LDH (U/L) & $1990.0 \pm 120.61^{\text {ns }}$ & $1814.3 \pm 224.08^{\text {ns }}$ & $1765.3 \pm 102.68^{\text {ns }}$ & $1888.5 \pm 237.01^{\text {ns }}$ \\
T. Chol ${ }^{2}(\mathrm{mg} / \mathrm{dL})$ & $51.6 \pm 5.64^{\text {ns }}$ & $56.5 \pm 4.20^{\text {ns }}$ & $48.75 \pm 4.40^{\text {ns }}$ & $60.5 \pm 1.48^{\text {ns }}$ \\
Glucose (g/dL) & $78.8 \pm 9.73^{\text {ns }}$ & $65.25 \pm 7.19^{\text {ns }}$ & $70 \pm 10.81^{\text {ns }}$ & $93.5 \pm 7.45^{\text {ns }}$ \\
\hline
\end{tabular}

${ }^{1)}$ T. Protein, total protein.

${ }^{2)}$ T. Chol, total cholesterol.

3) $\mathrm{ns}$, Means $\pm \mathrm{SD}(\mathrm{n}=5)$ within each column followed are not significantly different $(\mathrm{p}<0.05)$. 
널리 분포되어 있으며, 특히 심장, 간장, 신장 및 근육에 존재하며 급성간염등에서 $\mathrm{AST}, \mathrm{ALT}$ 와 함께 간세포로부터 빠져 나와서 급성간염초기에 증가 되는 것으로 알려져 있다 (17). 이러한 결과는 $t \mathrm{BHP}$ 에 의한 간의 손상으로부터 실크 단백질 산 가수분해물이 방어효과가 있음을 보여준다. 그 밖에 콜레스테롤, 알부민, 당, 단백질 등의 양에서는 실험군 간의 유의적인 차이는 없었고, 실크 단백질 산 가수분해물 을 투여한 후 $t \mathrm{BHP}$ 투여한 군의 혈액학적 검사결과 $\mathrm{WBC}$, $\mathrm{RBC}, \mathrm{Hb}, \mathrm{HCt}, \mathrm{MCV}, \mathrm{MCHC}, \mathrm{PLT}$ 수치에는 $t \mathrm{BHP}$ 만 투여 한 군과 비교하였을 때 $\mathrm{MCV}, \mathrm{MCH}, \mathrm{MCHC}$ 에서 군간의 약간의 유의적인 차이가 있었으나 수치상으로는 큰 차이가 나지 않았다(Table 3). 실크 단백질 가수분해물의 기능성에 대한 연구는 비교적 많이 이루어 졌다. 한 최근 연구는 실크 단백질 가수분해물이 당뇨 유발쥐 $(d b / d b$ mouse)에서 혈당 을 낮추고 췌장의 베타세포의 크기와 인슐린의 분비를 촉진 시키는 것으로 보고 하였다(18). 지방세포에서도 실크 단백
질 가수분해물은 글루코스의 세포내 흡수를 촉진하고 식욕 관련 호르몬인 렙틴의 유전자 발현을 억제 하는 것으로 관찰되었다(19). Zouh 등(20)은 alcalase로 처리된 실크 단백 질 가수분해물로부터 항 고혈압 활성을 확인하였으며 고혈 압 유발 체계중의 하나인 Agiotensin-converting enzyme (ACE)의 저해제로서 펩타이드를 분리하였다. 여러 연구들 에서 단백질 가수분해물 또는 펩타이드류의 간세포 또는 간 기능상에 관한 결과들이 보고되고 있다. Chiang 등은 감자에서 유래하는 펩타이드류가 고지방식이로부터 유도 되는 간세포의 괴사를 억제하는 것을 보고하였으며(21) 이 때 사용된 감자 유래 펩타이드의 농도는 $75 \mathrm{mg} / \mathrm{kg}$ 의 농도로 본 연구에서의 실크 단백질 가수분해물의 사용농도 (1-2 $\mathrm{g} / \mathrm{kg}$ )와 큰 차이를 보였는데 감자유래 펩타이드는 효소 가 수분해물인 반면 본 연구의 시료는 산 가수분해물로서 이는 효소의 선택적인 가수분해가 무작위적인 산 가수분해보다 활성 펩타이드의 생성을 증가시켰을 가능성이 있는 것으로

Table 2. Blood biochemical test on administration with silk protein hydrolysates and $t$ BHP $(0.1 \mathrm{mM} / \mathrm{kg})$

\begin{tabular}{|c|c|c|c|c|c|c|}
\hline \multirow{2}{*}{ Item } & \multicolumn{2}{|c|}{ No t-BHP } & \multicolumn{4}{|c|}{ Silk protein hydrolysates $(\mathrm{g} / \mathrm{kg})+\mathrm{t}-\mathrm{BHP}(0.1 \mathrm{mM} / \mathrm{kg})$} \\
\hline & 0 & 2 & 0 & 0.5 & 1 & 2 \\
\hline T. Protein ${ }^{1)}(\mathrm{g} / \mathrm{dL})$ & $\left.6.0 \pm 0.11^{\mathrm{ns} 3}\right)$ & $6.0 \pm 0.06^{\mathrm{ns}}$ & $5.9 \pm 0.12^{\mathrm{ns}}$ & $6.0 \pm 0.05^{\mathrm{ns}}$ & $6.0 \pm 0.07^{\mathrm{ns}}$ & $6.2 \pm 0.11^{\mathrm{ns}}$ \\
\hline Albumin $(\mathrm{g} / \mathrm{dL})$ & $3.8 \pm 0.09^{\mathrm{ns}}$ & $3.8 \pm 0.04^{\text {ns }}$ & $3.8 \pm 0.06^{\mathrm{ns}}$ & $3.9 \pm 0.05^{\mathrm{ns}}$ & $3.8 \pm 0.00^{\mathrm{ns}}$ & $3.9 \pm 0.1^{\text {ns }}$ \\
\hline ALP (U/L) & $272.8 \pm 34.10^{\mathrm{ns}}$ & $270 \pm 46.85^{\mathrm{ns}}$ & $275.3 \pm 27.0^{\mathrm{ns}}$ & $281.6 \pm 16.42^{\mathrm{ns}}$ & $272.0 \pm 10.85^{\mathrm{ns}}$ & $252.4 \pm 4.93^{\mathrm{ns}}$ \\
\hline AST (U/L) & $136.4 \pm 6.63^{(4)}$ & $141.8 \pm 6.34^{\text {cd }}$ & $196.2 \pm 6.99^{\mathrm{a}}$ & $173.0 \pm 8.10^{\mathrm{ab}}$ & $158.0 \pm 7.41^{\mathrm{c}}$ & $145.8 \pm 4.61^{\text {cd }}$ \\
\hline ALT (U/L) & $45.2 \pm 1.71^{\mathrm{e}}$ & $46.0 \pm 1.41^{\mathrm{e}}$ & $83.0 \pm 3.91^{\mathrm{a}}$ & $72.4 \pm 4.52^{b}$ & $60.2 \pm 1.83^{c}$ & $50.2 \pm 3.73^{\mathrm{d}}$ \\
\hline LDH (U/L) & $1,990.0 \pm 120.61^{\mathrm{c}}$ & $1,888.5 \pm 25.01^{\mathrm{c}}$ & $4,348.6 \pm 593.29^{\mathrm{a}}$ & $3286.2 \pm 362.84^{b}$ & $3,051.4 \pm 430.49^{b}$ & $3,068.6 \pm 220.84^{b}$ \\
\hline T. $\mathrm{Chol}^{2)}(\mathrm{mg} / \mathrm{dL})$ & $51.6 \pm 5.64^{\mathrm{ns}}$ & $60.5 \pm 1.48^{\mathrm{ns}}$ & $48.8 \pm 1.66^{\mathrm{ns}}$ & $51.2 \pm 3.81^{\mathrm{ns}}$ & $46.4 \pm 2.16^{\mathrm{ns}}$ & $50.4 \pm 3.41^{\mathrm{ns}}$ \\
\hline Glucose (g/dL) & $78.8 \pm 9.73^{\mathrm{ns}}$ & $93.5 \pm 7.45^{\mathrm{ns}}$ & $95.2 \pm 10.07^{\mathrm{ns}}$ & $71.6 \pm 14.06^{\mathrm{ns}}$ & $66 \pm 16.63^{\text {ns }}$ & $106.2 \pm 15.73^{\text {ns }}$ \\
\hline
\end{tabular}

T) Protein, total protein.

${ }^{2)}$ T. Chol, total cholesterol.

3) $\mathrm{ns}$, not significant.

${ }^{4}$ Values are expressed as means \pm SD for 5 rats. Values not sharing the same letter are significantly different, $p<0.05$.

Table 3. Hematologic test on administration with silk protein hydrolysates and $t$-BHP $(0.1 \mathrm{mM} / \mathrm{kg})$

\begin{tabular}{|c|c|c|c|c|c|c|}
\hline \multirow{2}{*}{ Item $^{1)}$} & \multicolumn{2}{|c|}{ No $t$-BHP } & \multicolumn{4}{|c|}{ Silk protein hydrolysates $(\mathrm{g} / \mathrm{kg})+t$-BHP $(0.1 \mathrm{mM} / \mathrm{kg})$} \\
\hline & 0 & 2 & 0 & 0.5 & 1 & 2 \\
\hline $\mathrm{RBC}\left(10^{6} / \mathrm{mm}^{3}\right)$ & $7.4 \pm 0.09^{\mathrm{ns} 2)}$ & $7.2 \pm 0.04^{\text {ns }}$ & $6.9 \pm 0.08^{\mathrm{ns}}$ & $7.1 \pm 016^{\mathrm{ns}}$ & $7.2 \pm 0.19^{\mathrm{ns}}$ & $7.2 \pm 0.17^{\mathrm{ns}}$ \\
\hline WBC $\left(10^{3} / \mathrm{mm}^{3}\right)$ & $7.1 \pm 1.16^{\mathrm{ns}}$ & $6.9 \pm 0.33^{\mathrm{ns}}$ & $5.2 \pm 0.56^{\mathrm{ns}}$ & $4.1 \pm 0.33^{\mathrm{ns}}$ & $7.1 \pm 1.00^{\mathrm{ns}}$ & $4.4 \pm 0.72^{\text {ns }}$ \\
\hline $\mathrm{HCt}(\%)$ & $51.3 \pm 0.77^{\mathrm{ns}}$ & $50.7 \pm 1.95^{\mathrm{ns}}$ & $50.2 \pm 0.81^{\mathrm{ns}}$ & $51.0 \pm 0.87^{\mathrm{ns}}$ & $53.6 \pm 0.90^{\mathrm{s}}$ & $52.3 \pm 1.18^{\mathrm{ns}}$ \\
\hline $\mathrm{Hb}(\mathrm{g} / \mathrm{dL})$ & $14.4 \pm 0.13^{\mathrm{ns}}$ & $14.6 \pm 0.19^{\mathrm{ns}}$ & $13.6 \pm 0.14^{\mathrm{ns}}$ & $14.0 \pm 0.32^{\mathrm{ns}}$ & $14.3 \pm 0.24^{\mathrm{ns}}$ & $14.0 \pm 0.30^{\mathrm{ns}}$ \\
\hline MCV (fL) & $69.2 \pm 1.09^{b 3)}$ & $70.2 \pm 0.81^{\mathrm{b}}$ & $72.4 \pm 0.85^{\mathrm{ab}}$ & $72.4 \pm 1.08^{\mathrm{ab}}$ & $74.4 \pm 1.09^{\mathrm{a}}$ & $72.3 \pm 0.94^{\mathrm{ab}}$ \\
\hline $\mathrm{MCH}(\mathrm{pg})$ & $19.42 \pm 0.19^{\mathrm{ab}}$ & $20.3 \pm 0.21^{\mathrm{a}}$ & $19.7 \pm 0.13^{\mathrm{ab}}$ & $19.9 \pm 0.07^{\mathrm{a}}$ & $19.8 \pm 026^{\mathrm{a}}$ & $19.3 \pm 0.19^{\mathrm{ab}}$ \\
\hline $\mathrm{MCHC}(\mathrm{g} / \mathrm{dL})$ & $28.16 \pm 0.26^{b}$ & $28.9 \pm 0.28^{\mathrm{a}}$ & $27.2 \pm 0.21^{b}$ & $27.5 \pm 0.40^{b}$ & $26.6 \pm 0.29^{b c}$ & $26.7 \pm 012^{\mathrm{bc}}$ \\
\hline PLT $\left(10^{3} / \mathrm{mm}^{3}\right)$ & $658.2 \pm 128.00^{\mathrm{ns}}$ & $540 \pm 103.93^{\text {ns }}$ & $833.5 \pm 26.31^{\mathrm{ns}}$ & $814.8 \pm 51.33^{\mathrm{ns}}$ & $836.4 \pm 120.05^{\mathrm{ns}}$ & $862 \pm 36.08^{\mathrm{ns}}$ \\
\hline
\end{tabular}

${ }^{1)} \mathrm{RBC}$, red blood cell count; WBC, white blood cell count; $\mathrm{HCt}$, hematocrit; $\mathrm{Hb}$, hemoglobin concentration; $\mathrm{MCV}$, mean corpuscular hemoglobin volume; MCH, mean corpuscular hemoglobin; MCHC, mean corpuscular hemoglobin concentration; PLT, platelet.

${ }^{2)}$ ns, not significant.

${ }^{3)}$ Values are expressed as means \pm SD for 5 rats. Values not sharing the same letter are significantly different, $p<0.05$. 
사료된다(21). Chung 등은(22) 옥수수 유래 단백질 가수분 해물의 간 보호 효과를 보고하였는데 이때 간 독성은 에탄 올을 사용하였으며 사용된 옥수수 유래 단백질 가수분해물 은 식이의 $1-3 \%$ 까지 수준이었고 특히, $3 \%$ 옥수수 유래 단백질 가수분해물의 투여로 알코올대사 효소인 alcohol dehydrogenase(ALD)의 활성이 $20 \%$ 증가한 반면, 알코올 유래 독성대사물질중의 하나인 acetaldehyde의 혈중 농도가 $60 \%$ 감소하였음을 보였다(22). 본 연구에서의 실크 단백질 가수분해물의 간 보호효과는 다른 연구들에 비해 비교적 높은 용량으로서 그 효과를 발휘하는 것으로 관찰되며 보다 세부적으로 차후 비교연구가 필요하다 하겠다. 또한, 본 연구에서는 산 가수분해물을 사용하여 실험을 하였지만 여러 효소를 사용하여 생성된 가수분해물에 대한 연구도 필요한 것으로 사료된다.

\section{과산화물 malondialdehyde(MDA)에 대한 실크단백질} 산 가수분해물의 영향

지질 과산화는 생체에서 자연적으로 발생될 수 있는 superoxide anion radical로부터 유래하는 각종의 free radical 에 의해 세포막의 다가 불포화지방산이 과산화 되는 현상을 지칭 한다(23). 이때 불포화지방산은 과산화 과정을 통해 분해되어 $\mathrm{MDA}$ 라고 하는 지질 과산화물을 생성한다. 이는 세포 내 산화스트레스에 대한 지표로 이용이 된다. 실크 단백질 산 가수분해물만 투여했을 경우 자발적으로 발생하 는 $\mathrm{MDA}$ 수치를 조금 감소( 20\%) 시키는 것으로 관찰 된다 (Fig. 1), $t$-BHP만 처리했을 경우 정상군에 비해 $\mathrm{MDA}$ 의 생성이 약 $37 \%$ 증가되었으며 이러한 $\mathrm{MDA}$ 의 증가는 실크 단백질 산 가수분해물 처리에 의해 유의적으로 감소되었 다. 실크 단백질 가수분해물 처리군은 $t \mathrm{BHP}$ 처리군에 비해 $\mathrm{MDA}$ 생성을 약 $45 \%$ 감소시켰고 $(2 \mathrm{~g} / \mathrm{kg})$, 실크 단백질 산 가수분해물의 농도간의 차이는 없었지만 $1 \mathrm{~g} / \mathrm{kg}$ 과 2 $\mathrm{g} / \mathrm{kg}$ 에서 정상적인 범위의 $\mathrm{MDA}$ 수치를 보였다(Fig. 1). 이 는 실크 단백질 산 가수분해물이 산화스트레스에 의해서 유도된 과산화지질의 생성을 유의적으로 억제함을 보여주 는 결과이다. 하지만, 혈액에서의 $\mathrm{MDA}$ 생성에서는 시료처 리군과 정상군간의 유의적인 차이는 보이지 않았다(Fig. 2). 이는 $t \mathrm{BHP}$ 가 체내에 투입이 되었을 때 우선 해독하기 위해 주로 간으로 이동하여 간에서 지질과산화를 발생시키 는 것으로 사료된다. $\mathrm{MDA}$ 에 대한 생성 억제작용을 가지는 단백질성 소재로 쌀의 부산물이 알려져 있으며 쌀의 저분자 량의 단백질 분획이 유의적으로 $t \mathrm{BHP}$ 에 의해 유도된 $\mathrm{MDA}$ 의 생성을 억제함이 보고되었다. 이때 동물실험에서 사용된 쌀 가수분해물은 $0.5-2 \mathrm{~g} / \mathrm{mL}$ 로 mass spectrometer와 $\mathrm{HPLC}$ 로 분석한 결과 분자량이 $700 \mathrm{Da}$ 이하인 것으로 알려 졌다(24). 따라서 본 연구에서의 실크 단백질 산 가수분해물 을 대상으로 간 보호효과를 보이는 분획을 분리 하여 펩타 이드의 조성을 밝히는 것이 필요하며 위에서 언급했듯이
효소별로 가수분해물의 특성과 활성을 비교하는 것도 가치 있는 실험이라고 사료된다. 그 밖에 발아 발효콩 추출물 또한 이러한 $\mathrm{MDA}$ 생성 억제작용을 가지는 것으로 알려져 있는데 발아 발효콩 추출물은 $0.5-1 \mathrm{~g} / \mathrm{kg}$ 의 고용량일 때 효과가 관찰되어 본 연구의 실크단백질 산 가수분해물의 활성 농도와 유사함을 보였으며 in vitro에서는 $0.5 \mathrm{mg} / \mathrm{mL}$ 의 농도에서 간세포 내 활성산소(ROS)의 생성을 $50 \%$ 이상 감소시키는 것으로 보고되었다(25).

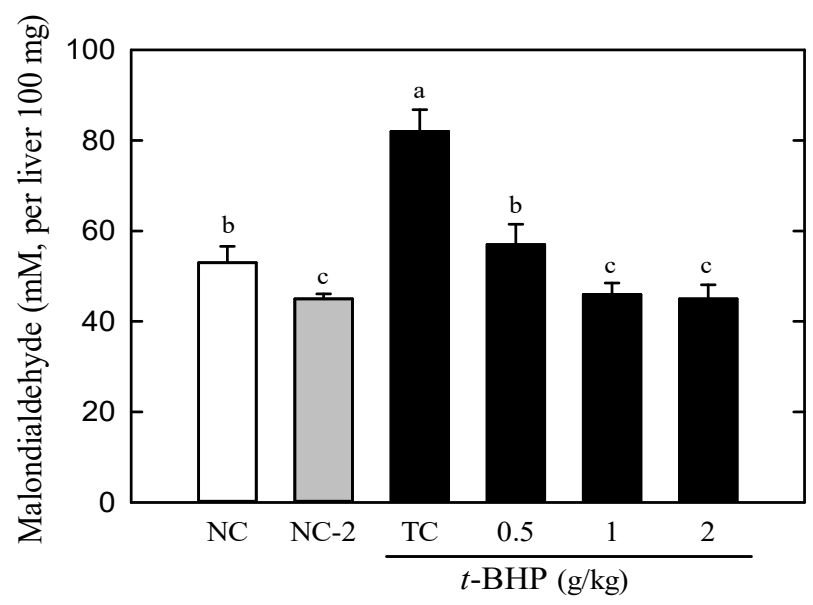

Fig. 1. Effect of silk protein hydrolysate on MDA production in $t$-BHP-treated SD rat liver.

$\mathrm{NC}$, normal control (no treatment); NC-2, normal control $+2 \mathrm{~g}$ of silk protein hydrolysate; TC, $\mathrm{t}-\mathrm{BHP}$ treated control.

Values are expressed as means \pm SD for 5 rats. Different letters indicate significant differences at $\mathrm{p}<0.05$.

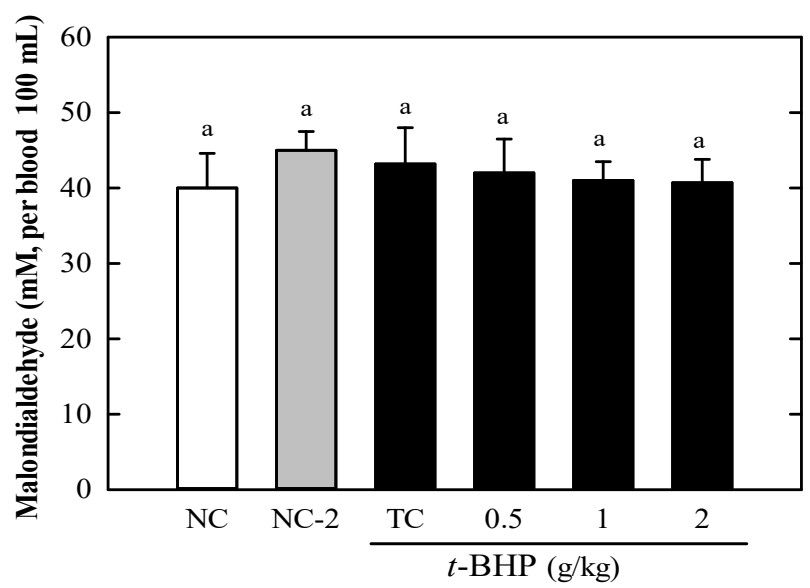

Fig. 2. Effect of silk protein hydrolysate on MDA production in $t$-BHP-treated SD rat blood.

$\mathrm{NC}$, normal control (no treatment); NC-2, normal control $+2 \mathrm{~g}$ of silk protein hydrolysate; TC, t-BHP treated control.

Values are expressed as means \pm SD for 5 rats. Different letters indicate significant differences at $\mathrm{p}<0.05$.

체내 글루타치온에 대한 실크단백질 산 가수분해물의 영향

$\mathrm{GSH}$ 는 체내에서 해독기능, 면역기능, 항산화 기능등의 핵심적인 역할을 하는 인체에서는 매우 중요한 해독제이며 


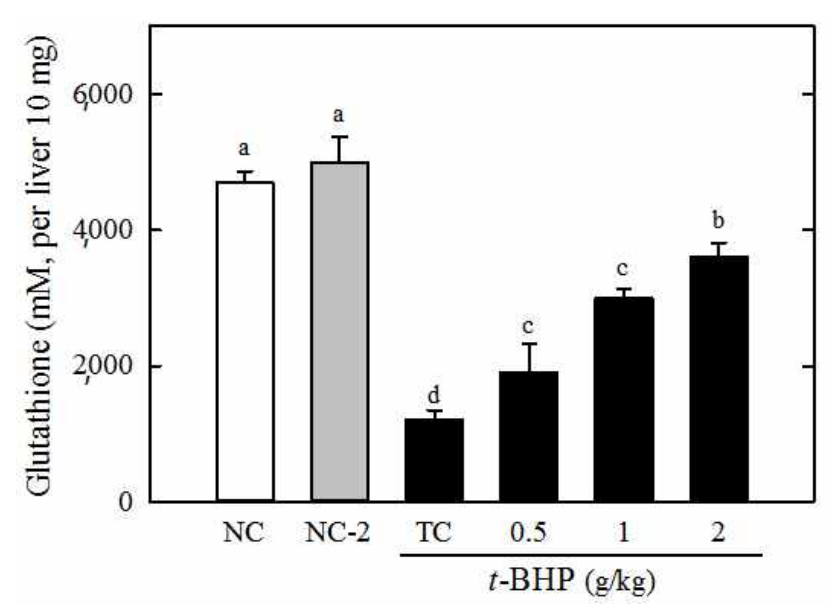

Fig. 3. Effect of silk protein hydrolysate on glutathione content in $t$-BHP-treated SD rat liver.

$\mathrm{NC}$, normal control (no treatment); NC-2, normal control $+2 \mathrm{~g}$ of silk protein hydrolysate; TC, t-BHP treated control.

Values are expressed as means $\pm \mathrm{SD}$ for 5 rats. Different letters indicate significant differences at $\mathrm{p}<0.05$.
둔화되면서 고용량 $(2 \mathrm{~g} / \mathrm{kg})$ 의 시료를 처리했을 때 $t \mathrm{BHP}$ 만 처리한 군에 비해 3배정도 GSH의 양이 증가하였다(Fig. $3)$. 이러한 결과는 실크 단백질 산 가수분해물이 $t \mathrm{BHP}$ 에 의한 $\mathrm{GSH}$ 의 감소를 효과적으로 억제한다는 것을 보여준 다. 실크 단백질에 의한 $\mathrm{GSH}$ 의 감소억제는 Fig. 1 에서 보이 는 지질 과산화물인 $\mathrm{MDA}$ 의 생성이 실크 단백질에 의해서 억제되는 것과 일맥상통한다. Nasri 등(27)은 어류인 모샘 치의 단백질 가수분해물이 고지방 및 고당 식이로부터 유도 되는 산화스트레스와 glutathione의 감소를 억제하는 것을 보고하였는데 이들의 활성농도는 $400 \mathrm{mg} / \mathrm{mL}$ 수준이어서 본 연구의 실크 단백질 가수분해물 활성농도와 약간의 차이 를 보였으며 특히, superoxide dismutase(SOD), glutathione peroxidase(Gpx), catalase 등의 항산화 효소들의 활성을 증 가시키는 것으로 보고되었다. 본 연구에서 과산화물인 $\mathrm{MDA}$ 와 항산화 물질인 glutathione에 대한 실크 단백질 가 수분해물의 조절작용이 확인되었기 때문에 세포내 산화스 트레스를 직접적으로 또는 간접적으로 조절 할 수 있는지를
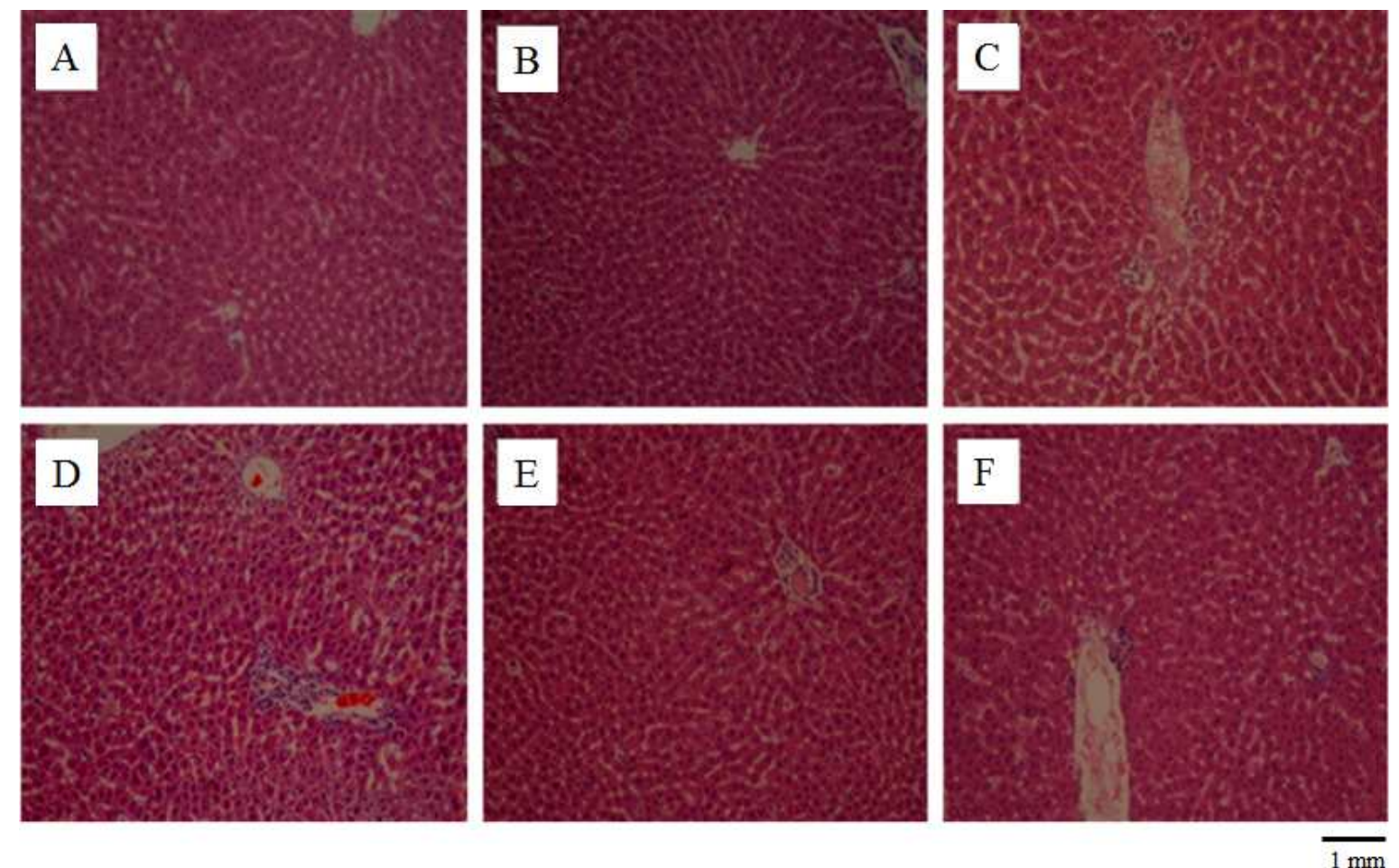

Fig. 4. Effects of silk protein hydrolysate on liver histology in rats treated with tert-butyl hydroperoxide ( $t$-BHP). Liver sections were stained with hematoxylin and eosin (H\&E) and examined under a microscope.

$\mathrm{A}$, normal control (untreated) group; B, normal control $+2 \mathrm{~g}$ of silk protein hydrolysate; $\mathrm{C}, t \mathrm{BHP}$-treated group; D, silk protein hydrolysate $(0.5 \mathrm{~g} / \mathrm{kg})$ pretreated group; E, silk protein hydrolysate $(1.0 \mathrm{~g} / \mathrm{kg})$ pretreated group; $\mathrm{F}$, silk protein hydrolysate $(2.0 \mathrm{~g} / \mathrm{kg})$ pretreated group.

강력한 항산화제이다(26). 본 연구에서 실크 단백질 산 가수 분해물의 체내 글루타치온에 대한 영향을 본 결과 $t \mathrm{BHP}$ 로 산화 스트레스를 유도하면 체내 글루타치온이 정상군에 비해서 $70 \%$ 이상 급격히 감소하는 것으로 나타났으며 실크 단백질 산 가수분해물을 투여했을 때 그러한 감소현상이
알아보기 위해 항산화 효소들의 활성과 발현양상에 어떠한 영향을 미칠지에 대해 향후 연구 해보는 것은 흥미로울 것으로 사료된다. 그 밖에 참마로부터 유래하는 discorin이 라고 하는 단백질은 $80 \mathrm{mg} / \mathrm{kg}$ 의 수준에서 동물에서 발생하 는 산화스트레스를 제어하는 일환으로 $\mathrm{GSH}$ 를 억제하는 
것으로 알려지고 있다(28). 일정한 분자량을 가지는 비교적 큰 단백질은 체내에서 소화되어 분해될 수 있기 때문에 단백질 유래 활성물질들은 주로 체내에서 소화 분해되어 펩타이드의 형태로 기능성을 나타내는 것으로 보이며 효소 및 산등의 단백질 가수분해물들 속에는 흡수에 있어서 소화 효소의 작용으로부터 자유로운 저분자로 존재하는 펩타이 드류가 다량 있을 것으로 사료된다.

\section{간과 신장조직의 조직학적 관찰}

세포는 괴사가 일어나게 되면 미토콘드리아의 팽창, 핵 의 축소, 세포소기관의 파괴, 팽창에 의한 세포막의 파괴, 리보솜, 리소좀의 융해 등이 일어나며 세포 내의 내용물이 세포외로 유출되어, 염증을 일으켜 $\mathrm{H \& E}$ 염색을 했을 시에 연분홍색을 띄게 된다(25). 쥐의 간 조직에서의 조직학적 변화를 알아보기 위해 $\mathrm{H} \& \mathrm{E}$ 염색을 한 결과 생리식염수만 투여한 대조군과 실크 단백질 산 가수분해물을 투여한 군에 서는 세포질과 원형의 핵이 모두 뚜렷하며 간세포의 괴사나 염증세포의 침윤과 같은 병변이 관찰되지 않았으나 $t \mathrm{BHP}$ 만 투여한 간 조직의 경우에는 혈관 주변으로 지방구변성과 괴사가 관찰되어 주변과 비교하였을 때 밝은 색을 띄었다 (Fig. 4) 시료를 투여하고 $t \mathrm{BHP}$ 를 투여한 군에서는 시료투 여 농도가 높아질수록 상태가 호전되어 대조군과 차이가 없는 것으로 관찰되었다. 이러한 결과는 간 조직이 $t \mathrm{BHP}$ 에
의해서 손상을 받게 되어 간 조직의 병변이 발생하지만 실크 단백질 산 가수분해물을 투여로 인해 $t \mathrm{BHP}$ 에 의한 손상으로부터 간을 보호하는 것으로 보여 진다. Han 등(24) 은 쌀 부산물 펩타이드 분획인 SRP-70이 쥐에서 $t$-BHP에 의해 유도되는 간 조직의 손상을 보호하는 것으로 보고되고 있어 본 연구에서 관찰된 실크 단백질 가수분해물로서 펩타 이드류의 간 조직 손상 방지효과와 연관이 있는 것으로 여겨진다(24). 한편, 누에고치 유충 분말이 디에틸니트로조 아민(diethylnitrosoamine)에 유도된 간 조직의 손상을 효과 적으로 차단 할 수 있음을 보고함으로써(29) 실크 단백질유 래 활성물질의 간 보호효과 면에서 본 연구와 일맥상통한다 고 할 수 있다. 신장의 경우 사구체의 테두리가 두꺼워 질 경우 신장의 기능 즉, 여과에 문제가 생겨 신장에 손상을 줄 수 있으나(30) $t$-BHP에 의해서 신장조직에서의 변화를 관찰할 수 없었고 생리식염수만 투여한 군과 $t \mathrm{BHP}$ 만 투여 한 군, 실크 단백질을 투여한 후 $t \mathrm{BHP}$ 를 투여한 군 간의 차이를 관찰 할 수 없었다(Fig. 5). 하지만, 한 최근 보고에서 고지방식이로부터 신장 기능의 이상이 유도 되었으며 어류 단백질의 효소 가수분해물이 이러한 요산의 감소와 크레아 틴의 증가를 동반하는 신장 기능 장애를 효과적으로 억제하 는 것으로 알려졌다(27). 이는 단백질 가수분해물이 간뿐만 아니라 신장도 여러 위해요소들로부터 보호 할 수 있음을 보여주는 것이라 할 수 있다.
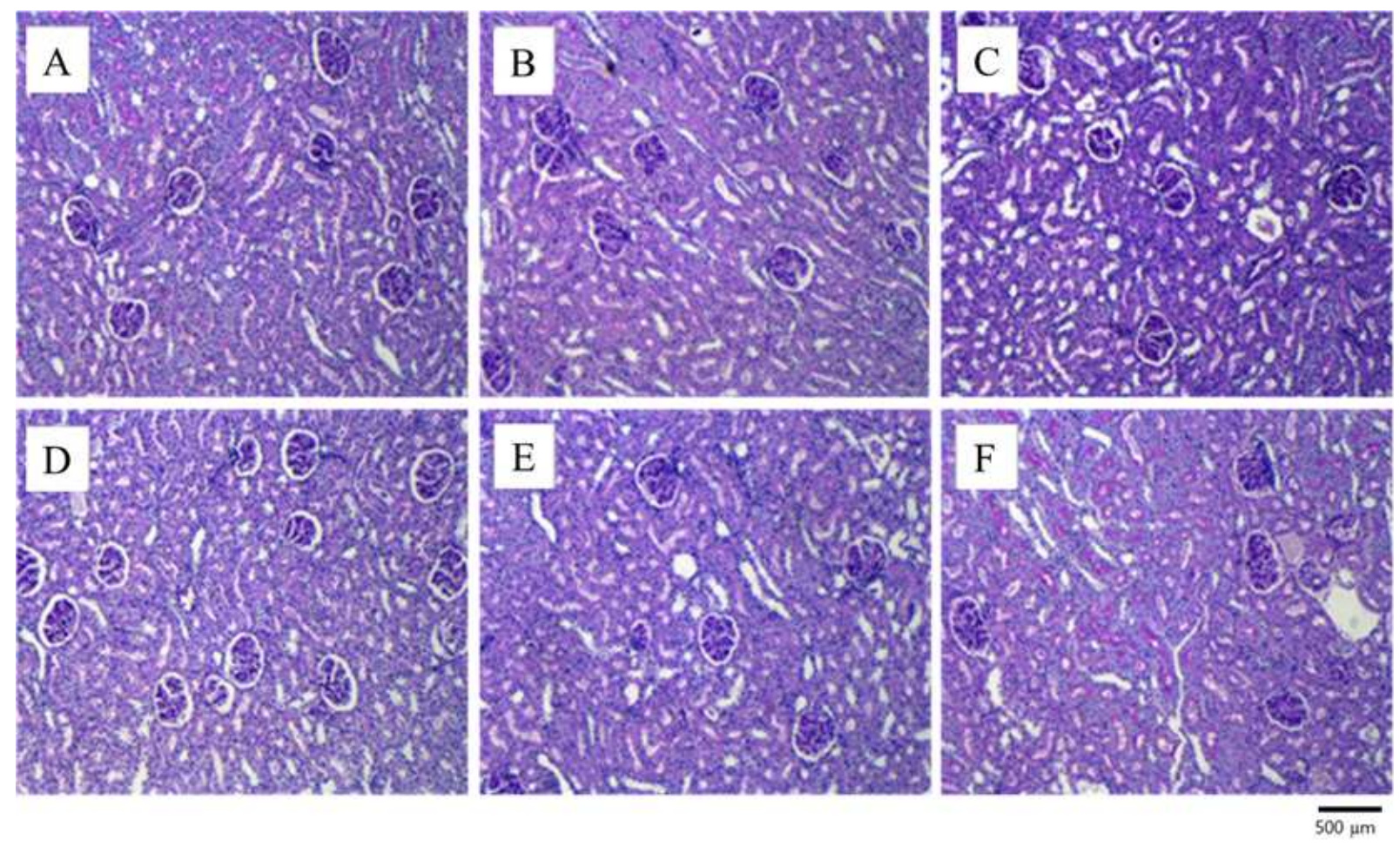

Fig. 5. Effects of silk protein hydrolysate on kidney histology in rats treated with tert-butyl hydroperoxide ( $t$-BHP). Kidney sections were stained with periodic acid and examined under a microscope.

$\mathrm{A}$, normal control (untreated) group; B, normal control $+2 \mathrm{~g}$ of silk protein hydrolysate; C, $t$ BHP-treated group; D, silk protein hydrolysate $(0.5 \mathrm{~g} / \mathrm{kg})$ pretreated group; $\mathrm{E}$, silk protein hydrolysate $(1.0 \mathrm{~g} / \mathrm{kg})$ pretreated group; F, silk protein hydrolysate $(2.0 \mathrm{~g} / \mathrm{kg})$ pretreated group. 


\section{요 약}

동물실험에서 실크단백질 산 가수분해물을 투여하고 $t \mathrm{BHP}$ 투여한 군의 혈액 생화학적 검사 결과 $t \mathrm{BHP}$ 만 투여 한 군과 비교하였을 때 AST, ALT 그리고 LDH가 실크단백 질 산 가수분해물의 투여 농도가 높아질수록 수치가 감소하 는 것으로 나타났고 세포가 손상할 시에 증가하는 $\mathrm{MDA}$ 를 간 조직을 대상으로 측정한 결과 실크단백질 산 가수분해물 의 농도가 높아질수록 수치가 대조군과 유사한 정도로 감소 하는 것으로 보아 간 손상에 관여하는 효소의 누출 억제 효과가 있는 것으로 사료된다. HPLC로 간 조직에서의 GSH 측정결과 $t \mathrm{BHP}$ 만 투여한 군과 비교하였을 때 유의적으로 증가하였고 조직학적 검사 결과 $\epsilon \mathrm{BHP}$ 만 투여한 군과 비교 하였을 때 실크단백질 산 가수분해물을 투여한 군이 대조군 과 가까운 모습을 보이는 것으로 관찰되어 실크단백질 산 가수분해물이 산화적 스트레스로부터의 간 보호 효과가 있는 것으로 사료된다. 따라서 실크단백질 산 가수분해물 의 기능적 소재로서의 이용가능성이 확대될 것으로 사료 된다.

\section{감사의 글}

이 논문은 2016학년도 서울여자대학교 교내 학술연구비 의 지원을 받았음.

\section{References}

1. Abdel-Misih SRZ, Bloomston M (2010) Liver Anatomy. Surg Clin North Am, 90, 643-653

2. Davis GL, Albright JE, Cook SF, Rosenberg DM (2003) Projecting future complications of chronic hepatitis $\mathrm{C}$ in the United States. Liver Transpl, 9, 331-338

3. Cesaratto L, Vascotto C, Calligaris S, Tell G (2004) The importance of redox state in liver damage. Ann Hepatol, 3, 86-92

4. Baud L, Ardaillou R (1993) Involvement of reactive oxygen species in kidney damage. Br Med Bull, 49, 621-629

5. Griffiths HR, Dowling EJ, Sahinoglu T, Blake DR, Parnham M, Lunec J (1992) The selective protection afforded by ebselen against lipid peroxidation in an ROS-dependent model of inflammation. Agents Actions, 36, 107-111

6. Lee KG, Yeo JH, Lee YW, Kweon HY, Woo SO, Han SM, Kim JH (2003) Studies on industrial utilization of silk protein. Food Science and Industry, 36, 25-37

7. Lee SH, Cho BN, Han CK, Joo SS (2002) Physiologic functionality of silk peptides- focus on antioxidant and immune function. Food Science and Industry, 35, 57-61

8. Hwang EH, Kang BG, Kim BR, Lee HJ (2001) Protein Quality Evaluation and Effect of Plasma Lipid Contents of Acid Hydrolysates of Cocoon in Rats Fed by High Cholesterol, High Triglyceride and High Sucrose Diet.

J Korean Soc Food Sci Nutr, 30, 1004-1009

9. Lee JS, Kim DI, Kim JM, Park SH, Choi JH, Lee KG, Yeo JH, Lee YW (2000) Effects of silk fibroin on oxidative stress and membrane fluidity in brain of SD Rats. Kor Soc Life Sci, 29, 106-106

10. Kim, AJ, Kim, SY, Choi MK, Kim MH, Han MR, Chung KS (2005) Effects of mulberry leaves powder on lipid metabolism in high cholesterol-fed rats. Korean J Food Sci Technol, 37, 636-641

11. Park, IK, Lee JO, Lee HS, Seol KY, Ahn YJ (1988) Cytotoxic Activity of Bombyx mori and Morus alba Derived Materials against Human Tumor Cell Lines. Agric Chem Biotech, 41, 187-190

12. Wang CJ, Wang JM, Lin WL, Chu CY, Chou FP, Tseng TH (2000). Protective effect of Hibiscus anthocyanins against tert-butyl hydroperoxide-induced hepatic toxicity in rats. Food Chem Toxicol, 38, 411-416

13. Reed DJ (1986) Regulation of reductive processes by glutathione. Biochem Pharmacol, 35, 7-13

14. Lee HS, Won NH, Kim KH, Lee HJ, Jun WJ, Lee KW (2005) Antioxidant effects of aqueous extract of Terminalia chebula in vivo and in vitro. Biol Pharm Bull, 28, 1639-1644

15. Davies MJ (1989) Detection of peroxyl and alkoxyl radicals produced by reaction of hydroperoxides with rat liver microsomal fractions. Biochem J, 257, 603-606

16. Kucera O, Endlicher R, Rousar T, Lotkova H, Garnol T, Drahota Z, Cervinkova Z (2014) The effect of tert-butyl hydroperoxide-induced oxidative stress on lean and steatotic rat hepatocytes in vitro. Oxid Med Cell Longev, 2014, 752506

17. Cassidy WM, Reynolds TB (1994) Serum lactic dehydrogenase in the differential diagnosis of acute hepatocellular injury. J Clin Gastroenterol, 19, 118-121

18. Do SG, Park JH, Nam HJ, Kim JB, Lee JY, Oh YS, Suh JG (2012) Silk fibroin hydrolysate exerts an anti-diabetic effect by increasing pancreatic $\beta$ cell mass in C57BL/KsJ-db/db mice. J Vet Sci, 13, 339-344

19. Lee HS, Lee HJ, Suh HJ (2011) Silk protein hydrolysate 
increases glucose uptake through up-regulation of GLUT 4 and reduces the expression of leptin in 3T3-L1 fibroblast. Nutr Res, 31, 937-943

20. Zhou F, Xue Z, Wang J (2010) Antihypertensive effects of silk fibroin hydrolysate by alcalase and purification of an ACE inhibitory dipeptide. J Agric Food Chem, $58,6735-6740$

21. Chiang WD, Huang CY, Paul CR, Lee ZY, Lin WT (2016) Lipolysis stimulating peptides of potato protein hydrolysate effectively suppresses high-fat-diet-induced hepatocyte apoptosis and fibrosis in aging rats. Food Nutr Res, 60, 31417

22. Chung YI, Bae IY, Lee JY, Chun HS, Lee HG (2009) Protective effects of branched-chain amino acid (BCAA)-enriched corn gluten hydrolysates on ethanol-induced hepatic injury in rats. Korean J Food Sci Technol, 41, 706-711

23. Draper HH, Hadley M (1990) Malondialdehyde determination as index of lipid Peroxidation. Methods Enzymol, 186, 421 - 431

24. Han BK, Park YH, Choi HS, Suh HJ (2016) Hepatoprotective effects of soluble rice protein in primary hepatocytes and in mice. J Sci Food Agric, 96, 685-694

25. Kim EY, Hong KB, Suh HJ, Choi HS (2015) Protective effects of germinated and fermented soybean extract against tert-butyl hydroperoxide-induced hepatotoxicity in HepG2 cells and in rats. Food Funct, 6, 3512-3521

26. Lushchak VI (2012) Glutathione homeostasis and functions: potential targets for medical interventions. J Amino Acids, 2012, 736837

27. Nasri R, Abdelhedi O, Jemil I, Daoued I, Hamden K, Kallel C, Elfeki A, Lamri-Senhadji M, Boualga A, Nasri M, Karra-Chaabouni M (2015) Ameliorating effects of goby fish protein hydrolysates on high-fat-high-fructose diet-induced hyperglycemia, oxidative stress and deterioration of kidney function in rats. Chem Biol Interact, 242, 71-80

28. Han CH, Lin YF, Lin YS, Lee TL, Huang WJ, Lin SY, Hou WC (2014) Effects of yam tuber protein, dioscorin, on attenuating oxidative status and learning dysfunction in d-galactose-induced BALB/c mice. Food Chem Toxicol, 65, 356-363

29. Cho JM, Kim KY, Ji SD, Kim EH (2016) Protective Effect of Boiled and Freeze-dried Mature Silkworm Larval Powder Against Diethylnitrosamine-induced Hepatotoxicity in Mice. J Cancer Prev, 21, 173-181

30. Slack A, Yeoman A, Wendon J (2010) Renal dysfunction in chronic liver disease. Critical Care, 14, 214-223 